Artikel Penelitian

\title{
Prototype Penyimpanan Buah dan Sayur Menggunakan Ozon dan Metode Evaporative Cooling sebagai Sistem Pendingin
}

\section{Prototype Fruit and Vegetable Storage using Ozon and Evaporative Cooling Method as Cooling System}

Aji Prasetyaningrum*, Muqsit Bramantiya, Alwi Meidianto, Pajar Saputra, Fauzia Dara Qonita, Nadia Sevi Ardiana

Fakultas Teknik, Jurusan Teknik Kimia, Universitas Diponegoro, Semarang

*Korespondensi dengan penulis (ajiprasetyaningrum@gmail.com)

Artikel ini dikirim pada tanggal 20 Juni 2016 dan dinyatakan diterima tanggal 29 Desember 2016. Artikel ini juga dipublikasi secara online melalui www.jatp.ift.or.id. Hak cipta dilindungi undang-undang. Dilarang diperbanyak untuk tujuan komersial.

Diproduksi oleh Indonesian Food Technologists® (C2017

\section{Abstrak}

Buah dan sayur merupakan bahan pangan yang bernilai gizi tinggi dan sangat bermanfaat bagi kesehatan. Namun, selama penyimpanan terjadi penurunan kualitas pada buah dan sayur yang disebabkan oleh tumbuhnya bakteri dan mikroorganisme. Metode pengawetan yang efektif, hemat energi dan ramah lingkungan dibutuhkan untuk memperpanjang masa simpan buah dan sayur tersebut. Penelitian ini bertujuan untuk menghasilkan sebuah prototype untuk mengatasi permasalahan tersebut. Prototype yang dirancang memanfaatkan ozon dan evaporative cooling untuk sistem pendinginan. Reaktor Dielectric Barrier Discharge (DBD) dengan konfigurasi elektrode jaringjaring digunakan untuk menghasilkan ozon sebagai desinfektan. Pembangkitan ozon membutuhkan daya total sebesar 15 watt. Pot refrigerator digunakan sebagai sistem pendingin hemat energi. Kondisi pada tempat penyimpanan, jumlah bakteri dan kondisi fisik pada buah dan sayur digunakan untuk menguji prototype. Prototype yang dihasilkan mampu mencapai suhu $25^{\circ} \mathrm{C}$ dengan relative humidity sebesar $95 \%$ pada tempat penyimpanannya. Buah dan sayur dengan jumlah bakteri awal sebanyak $6,5 \times 10^{3} \mathrm{CFU} / 100 \mathrm{~mL}$ mampu berkurang menjadi $3,5 \times 10^{3} \mathrm{CFU} / 100 \mathrm{~mL}$ setelah dicuci menggunakan ozon. Setelah penyimpanan selama tiga hari jumlah bakterinya menjadi $5,6 \times 10^{3} \mathrm{CFU} / 100 \mathrm{~mL}$, sedangkan variabel kontrol mencapai $16,6 \times 10^{3} \mathrm{CFU} / 100 \mathrm{~mL}$. Treatment yang dilakukan mampu menghambat perkembangan bakteri hingga dua kali lipatnya. Prototype yang dihasilkan mampu meningkatkan massa buah dan sayur dengan tampilan yang lebih segar dibanding variabel kontrol setelah disimpan selama tiga hari.

Kata kunci : buah, ozon, pengawetan, prototype, sayur

\section{Abstract}

Fruits and vegetables were known as a food with high nutritional value and providing beneficial to health. However, after the harvest and during storage there was a decrease in the quality of fruits and vegetables caused by the growth of bacteria and microorganisms. This study aimed to produce a prototype to overcome these problem. Prototype was designed to utilize ozone and evaporative cooling for refrigeration. The conditions at the storage place, the number of bacteria, and the physical condition of the fruit and vegetables were used to test the prototype. The prototype reached temperatures of $25^{\circ} \mathrm{C}$ with a relative humidity of $95 \%$ in storage. Fruits and vegetables with the initial bacterial counts as much as $6.5 \times 10^{3} \mathrm{CFU} / \mathrm{ml}$ was able to be reduced to $3.5 \times 10^{3} \mathrm{CFU} / \mathrm{ml}$ after washing using ozone. After storage for three days the amount of bacteria was $5.6 \times 10^{3} \mathrm{CFU} / \mathrm{ml}$, whereas the control variable reached $16.6 \times 10^{3} \mathrm{CFU} / \mathrm{ml}$. Treatment could inhibit the growth of bacteria up to twice. The resulting prototype was able to increase the mass of fruits and vegetables with a fresh look compared to the control three days of storage.

Keywords : fruits, ozone, preservation, prototype, vegetables

\section{Pendahuluan}

Buah dan sayur merupakan salah satu bahan pangan yang dibutuhkan oleh masyarakat. Menurut data BPS (2015) produksi buah dan sayur di Indonesia setiap tahunnya mengalami peningkatan. Buah dan sayur dipanen mengalami penurunan kualitas setelah dilakukan panen (Artés et al., 2009). Penurunan kualitas buah dan sayur terjadi akibat adanya pertumbuhan mikrooganisme (Bozkurt et al., 2016) dan proses pematangan (Kasso dan Bekele., 2016). Untuk meningkatkan masa simpan buah dan sayur setalah panen dapat dilakukan dengan cara konvensional seperti pemanasan, pendinginan atau merubahnya menjadi jenis yang makanan lain, seperti jus buah (Miller et al., 2013).
Proses pendingian pada buah dan sayur dapat menghambat proses pertumbuhan bakteri dan mengurangi laju pemantangan (Alhamdan et al., 2015). Penggunaan metode ini tidak dapat membunuh bakteri yang terdapat pada buah dan sayur. Untuk menghilangkan bakteri tersebut dibutuhkan metode tertentu seperti pemanasan, High Pressure Package (HPP), radiasi ultraviolet, ultrasonik, medan listrik, iradiasi dan plasma dingin (Li dan Farid., 2016). Pengembangan teknologi plasma untuk menghasilkan ozon telah banyak dikembangkan dalam bidang pangan (Patil et al., 2014). Ozon memiliki sifat oksidator kuat yang dapat digunakan untuk membunuh bakteri pada bahan pangan (Lyu et al. 2016). Keunggulan teknologi ozon adalah "green technology", karena tidak 
meninggalkan residu dan ozon mudah terdekomposisi menjadi oksigen (Lovato et al., 2009). Penggunaan suhu yang tinggi merupakan salah satu penyebab ozon mudah terdekomposisi menjadi oksigen (Sung et al., 2013). Oleh karena itu, kombinasi penggunaan ozon dan pendinginan dapat digunakan untuk memperpanjang masa simpan buah dan sayur.

Penelitian ini bertujuan untuk menghasilkan prototype alat penyimpanan buah dan sayur. Untuk menurunkan konsumsi daya yang dibutuhkan, maka sistem pendigin menggunakan metode Evaporative Cooling (Anyanwu, 2004). Sistem pendingin dirancang menggunakan pot refrigerator yang mampu menghasilkan suhu dibawah suhu ruangan (Date, 2012). Ozon dihasilkan menggunakan reaktor jenis Dielectric Barrier Discharge (DBD) dengan konfigurasi elektrode jaring-jaring.

\section{Materi dan Metode}

Materi

Alat yang digunakan adalah pembangkit ozon menggunakan reactor lucutan korona jenis dielectric barrier discharge (DBD) dengan konfigurasi jaringjaring. Lucutan plasma dihasilkan dari sumber tegangan $6 \mathrm{KV}$ dengan spesifikasi total daya 15 watt. Sistem dirancang secara semi batch dengan laju alir gas ozon 3 L/menit. Refrigerator dirancang menggunakan pot tanah liat dengan logam silinder berada dibagian dalam. Termometer ruangan (p.a Corona) digunakan untuk mengukur suhu didalam tempat penyimpanan.

Bahan yang digunakan pada penelitian ini adalah $\mathrm{H}_{2} \mathrm{SO}_{4}$ (p.a Merck), $\mathrm{Na}_{2} \mathrm{~S}_{2} \mathrm{O}_{3}$ (p.a Merck), KI (p.a Merck), indikator amilum, pasir dan silica gel. Pasir diletakkan diantara pot tanah liat dan logam silinder (Gambar 1). Pasir tersebut dibasahi dengan air untuk difungsikan sebagai pendingin menggunakan metode Evaporative Cooling. Penelitian ini menggunakan anggur merah (Vitis vinifera), caisim (Brassica rapa kelompok pekinensis) dan sawi putih (Brassica rapa kelompok parachinensis) sebagai sampel buah dan sayur. Petrifilm (3M) digunakan sebagai media untuk menguji jumlah total bakteri sebelum dan sesudah treatment pada buah dan sayur.

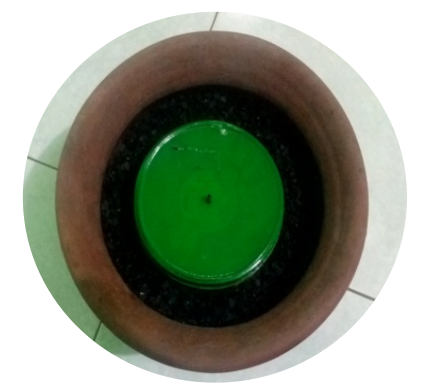

Gambar 1. Sistem Pendingin Pot Refrigerator Tampak Atas

\section{Metode}

Penelitian dilakukan di Laboratorium Pengolahan Limbah Jurusan Teknik Kimia Fakultas Teknik Universitas Diponegoro selama periode Januari-April 2016. Buah dan sayur dibedakan menjadi dua kelompok yaitu dicuci dengan ozon kemudian disimpan pada sistem pendingin dengan dialir ozon (variabel treatment), dan tanpa dicuci kemudian disimpan pada ruangan terbuka (variabel kontrol).

1. Pelarutan ozon

Ozon yang dihasilkan oleh ozon generator dialirkan kedalam air untuk proses pelarutan. Ozon dilarutkan kedalam air pada berbagai waktu berbeda.

2. Pencucian

Buah dan sayur dicuci dengan air yang telah dilarutkan ozon. Proses pencucian dilakukan dengan cara membasuh buah dan sayur sebanyak dua kali. Buah dan sayur yang telah dicuci kemudian disimpan didalam pot refrigerator.

\section{Pengawetan}

Buah dan sayur sebelum disimpan diujikan terlebih dahulu jumah total koloninya. Kemudian buah dan sayur disimpan didalam pot refrigerator selama tiga hari. Setiap hari ozon dialirkan kedalam pot refrigerator selama lima menit. Setelah disimpan selama tiga hari dilakukan kembali pengujian total koloni pada buah dan sayur.

4. Pengujian

Suhu didalam pot refrigerator diukur menggunakan termometer ruangan. Ozon yang terlarut didalam air dihitung menggunakan Persamaan (1), (Rakness et al. 1996). Kemudian buah dan sayur yang telah dicuci dijadikan jus kemudian dianalisa jumlah bakterinya menggunakan metode Total Plate Count (TPC). Pengamatan fisik juga dilakukan dengan membandingkan buah dan sayur yang telah disimpan selama tiga hari didalam pot refrigerator dan ruangan terbuka.

$$
\text { Konsentrasi Ozon (ppm) }=\frac{\mathrm{BM} \mathrm{O}_{3} \times \mathrm{VNa}_{2} \mathrm{~S}_{2} \mathrm{O}_{3} \times \mathrm{N} \mathrm{Na}_{2} \mathrm{~S}_{2} \mathrm{O}_{3}}{\text { Volume Sampel } \times e \mathrm{Na}_{2} \mathrm{~S}_{2} \mathrm{O}_{3}} \ldots \text { (1) }
$$

\section{Hasil dan Pembahasan}

Kinerja Pot Refrigerator

Menurut analisa yang dilakukan Date (2012) suhu didalam pot refrigerator mampu berada dibawah suhu sekitarnya. Pengukuran menggunakan termometer menujukkan suhu didalam pot refrigerator mencapai $25^{\circ} \mathrm{C}$, dibawah suhu kamar, yaitu $30^{\circ} \mathrm{C}$. Suhu didalam pot refrigerator berada dibawah suhu sekitarnya, akibat adanya penguapan air yang terkandung di dalam pasir. Air akan menyerap panas disekitarnya untuk proses penguapan sehingga suhu menjadi turun. Panas disekitar pasir tersebut akan ditransferkan kedalam pot refrigerator, sehingga suhu didalamnya juga menjadi lebih dingin.

Selain menurunkan suhu system pot refrigerator juga mampu untuk meningkatkan nilai relative humidity dibandingkan lingkungan sekitarnya (Date, 2012). Nilai relative humidity didalam pot refrigerator dihitung menggunakan psychometric chart (Poling et al., 2008). Hasil sebesar $95 \%$ relative humidity didapatkan didalam pot refrigerator, sedangkan nilai relative humidity disekitar alat mencapai $70 \%$. Suhu dan relative humidity yang didapatkan sesuai dengan analisa yang dilakukan oleh Date (2012) dengan suhu lebih rendah dan relative humidity lebih tinggi. 


\section{Ozon Terlarut}

Konsentrasi ozon yang terlarut didalam air untuk mencuci buah dan sayur diuji dengan metode iodometri. Proses pelarutan ozon selama lima menit mampu menghasilkan ozon terlarut sebesar 33,6 ppm (Figur 1). Konsentrasi tersebut tergolong tinggi karena ozon terlarut dengan konsentrasi berkisar antara 0,03$20 \mathrm{ppm}$ dapat digunakan untuk membunuh bakteri (Ramos et al., 2013).

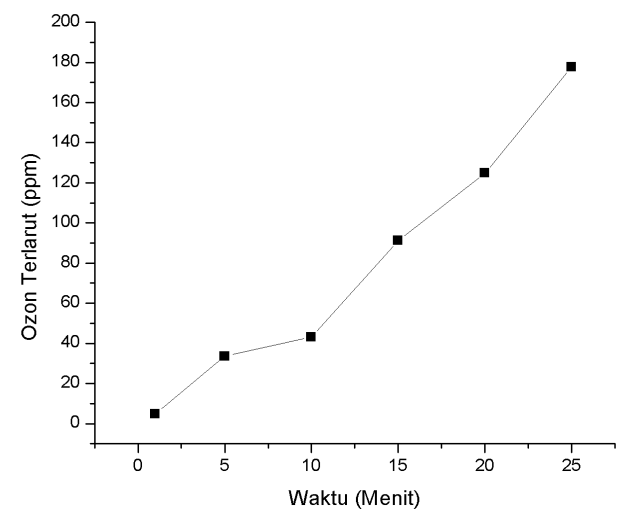

Figur 1. Konsentrasi Ozon Terlarut Pada Berbagai Waktu

Jumlah Bakteri pada Buah dan Sayur

Total jumlah bakteri yang terdapat pada buah dan sayur diuji menggunakan metode TPC. Pada hari ke-0 untuk variabel kontrol memiliki jumlah bakteri sebanyak $6,5 \times 10^{3} \mathrm{CFU} / 100 \mathrm{ml}$. Setelah dilakukan treatment jumlah bakteri berkurang menjadi $3,5 \times 10^{3}$ CFU/100ml. Proses pencucian dengan ozon mampu menghilangkan bakteri hingga $46 \%$ dari jumlah awal. Penurunan tersebut masih belum cukup signifikan karena proses pencucian buah dan sayur berlangsung relatif singkat.

Figur 2 menunjukkan perkembangan bakteri pada buah dan sayur selama tiga hari. Pada variabel treatment memiliki jumlah bakteri sebanyak $5,6 \times 10^{3}$ CFU/100ml, sedangkan variabel kontrol $16,6 \times 10^{3}$ CFU/100ml. Selama tiga hari, bakteri pada variabel treatment mengalami perkembangan sebanyak $2,1 \times 10^{3}$ $\mathrm{CFU} / 100 \mathrm{ml}$, sedangkan pada kontrol negatif mengalami perkembangan hingga $1,01 \times 10^{4} \mathrm{CFU} / 100 \mathrm{ml}$.

Konstanta perkembangan bakteri dan doubling time pada perkembangannya dapat dihitung menggunakan Persamaan 2 dan 3 (Widdel, 2007). Hasil menunjukkah bahwa buah dan sayur yang ditreatment mampu menghambat perkembangan bakterinya. Nilai konstanta perkembangan bakteri dan doubling time pada buah dan sayur dapat dilihat pada Tabel 1. Treatment pada buah dan sayur menggunakan ozon dan pendingin pot refrigerator mampu menghambat perkembangan bakteri hingga dua kali lipatnya.

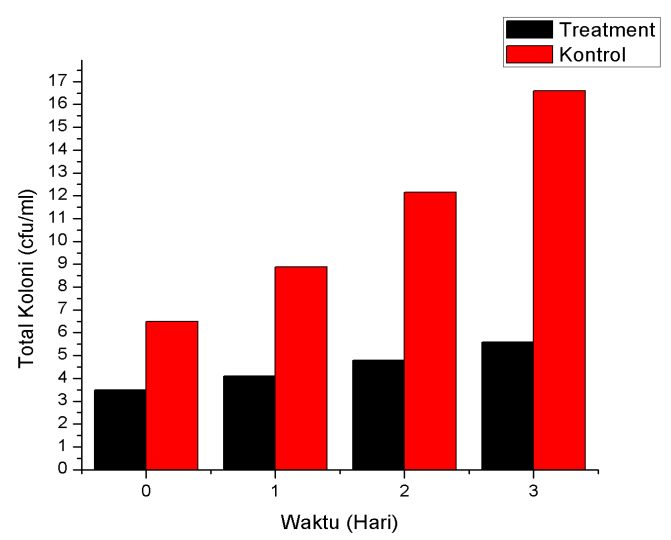

Figur 2. Perkembangan Bakteri pada Buah dan Sayur

$$
\begin{aligned}
\mu=\frac{1}{t-t_{0}}\left(\ln \frac{N}{N_{0}}\right) \ldots(2) & \\
t_{d}=\frac{1}{\mu}\left(\ln \frac{N}{N_{0}}\right) \ldots(3) & \\
\text { Dimana } \quad \mu & =\text { Konstanta perkembangan bakteri } \\
\mathrm{t} & =\text { waktu } \\
\mathrm{t}_{0} & =\text { waktu mula-mula } \\
\mathrm{t}_{\mathrm{d}} & =\text { doubling time } \\
\mathrm{N} & =\text { Jumlah bakteri saat waktu }(\mathrm{t}) \\
\mathrm{N}_{0} & =\text { Jumlah bakteri saat waktu }\left(\mathrm{t}_{0}\right)
\end{aligned}
$$

Tabel 1. Konstanta Perkembangan Bakteri dan Doubling Time

\begin{tabular}{ccc}
\hline Variabel & $\mu\left(\right.$ hari $\left.^{-1}\right)$ & $\mathrm{t}_{d}$ (hari) \\
\hline Treatment & 0,157 & 4,424 \\
Kontrol & 0,313 & 2,218 \\
\hline
\end{tabular}

Kondisi Fisik pada Buah dan Sayur

Tabel 2 dan Gambar 2 menunjukkan bahwa variabel treatment memiliki tampilan fisik yang lebih baik dibandingkan dengan variabel kontrol. Penyimpanan selama tiga hari telah menunjukkan perbedaan signifikan antara variabel treatment dan variabel kontrol. Kontrol menunjukkan telah mengalami pembusukan, sedangkan pada variabel treatment masih menunjukkan kondisi segar.
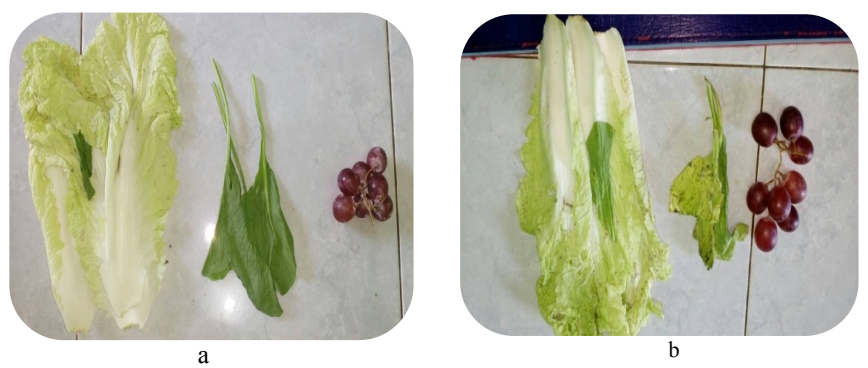

Gambar 2. Tampilan Fisik Buah dan Sayur (a. Treatment; b. Kontrol) 
Tabel 2. Hasil Tampilan Fisik pada Buah dan Sayur

\begin{tabular}{|c|c|c|c|c|c|c|c|}
\hline \multirow{2}{*}{ Sampel } & \multirow{2}{*}{ Hari } & \multicolumn{3}{|c|}{ Kontrol Negatif } & \multicolumn{3}{|c|}{ Treatment } \\
\hline & & Warna & Tekstur & Aroma & Warna & Tekstur & Aroma \\
\hline Anggur Merah & & Cerah & Padat & Segar & Cerah & Padat & Segar \\
\hline Sawi Putih & $\mathrm{Ke}-\mathrm{O}$ & Cerah & Padat & Segar & Cerah & Padat & Segar \\
\hline Caisim & & Cerah & Padat & Segar & Cerah & Padat & Segar \\
\hline Anggur Merah & & Gelap & Lunak & Segar & Cerah & Padat & Segar \\
\hline Sawi Putih & $\mathrm{Ke}-1$ & Pucat & Lunak & Busuk & Cerah & Lunak & Segar \\
\hline Caisim & & Pucat & Layu & Busuk & Cerah & Padat & Segar \\
\hline Anggur Merah & & Gelap & Lunak & Busuk & Cerah & Padat & Segar \\
\hline Sawi Putih & $\mathrm{Ke}-2$ & Pucat & Lunak & Busuk & Pucat & Padat & Segar \\
\hline Caisim & & Pucat & Layu & Busuk & Pucat & Padat & Segar \\
\hline Anggur Merah & & Gelap & Lunak & Busuk & Cerah & Padat & Segar \\
\hline Sawi Putih & $\mathrm{Ke}-3$ & Pucat & Lunak & Busuk & Pucat & Padat & Segar \\
\hline Caisim & & Pucat & Layu & Busuk & Pucat & Padat & Segar \\
\hline
\end{tabular}

Buah dan sayur yang ditreatment didalam prototype memiliki kualitas yang lebih baik secara fisik diakibatkan adanya penghambatan perkembangan bakteri serta suhu penyimpanan yang lebih dingin. Perkembangan bakteri yang terhambat menyebabkan jumlah bakteri pada buah dan sayur semakin sedikit, sehingga proses pembusukan dapat dihambat (Bozkurt et al., 2016). Selain itu, penyimpanan pada suhu dingin juga mampu memperlambat proses pematangan (Alhamdan et al., 2015). Prototype dengan kombinasi ozon dan pendigin terbukti secara efektif sebagai media penyimpan.
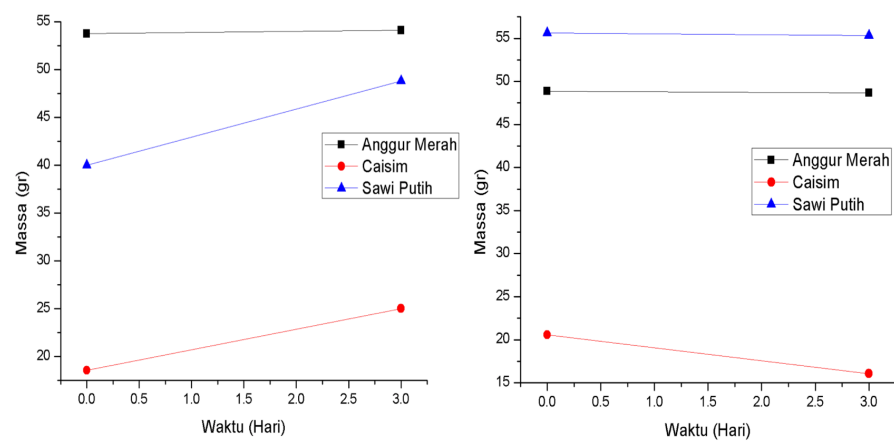

Figur 3. Perubahan Massa yang Terjadi pada Buah dan Sayur (Figur kiri adalah treatment; Figure kanan adalah kontrol)

Figur 3 menunjukkan terjadi adanya perubahan massa pada buah dan sayur yang telah disimpan selama tiga hari. Proses tersebut terjadi akibat adanya perpindahan massa air (Watanabe et al., 2015). Pada variabel treatment terjadi pertambahan berat pada buah dan sayur. Sistem pot refrigerator yang mampu menurunkan suhu dan meningkatkan relative humidity menjadi penyebab kenaikan massa pada buah dan sayur yang disimpan dalam prototype. Relative humidity yang semakin tinggi menjadi indikator tingginya kadar air disekitar, sehingga terjadi perpindahan massa air dari udara menuju kedalam buah dan sayur. Pada variabel kontrol terjadi penurunan massa yang diakibatkan karena terjadi proses perpindahan massa air dari buah dan sayur ke udara sekitar (Becker et al., 2014).

\section{Kesimpulan}

Hasil pengujian menunjukkan suhu penyimpanan didalam pot refrigerator mampu mencapai $25^{\circ} \mathrm{C}$ dengan relative humidity sebesar $95 \%$. Buah dan sayur yang ditreatment mampu menghambat perkembangan bakteri hingga dua kali lipatnya. Buah dan sayur yang disimpan didalam prototype selama tiga hari mengalami peningkatan massa buah dan sayur dengan tampilan yang lebih segar dibanding variabel kontrol setelah disimpan selama tiga hari.

\section{Ucapan Terima Kasih}

Ucapan terima kasih disampaikan kepada Direktorat Riset dan Pengabdian Masyarakat (DRPM) DIKTI tahun anggaran 2016 yang membantu dalam pendanaan kegiatan penelitian ini.

\section{Daftar Pustaka}

Alhamdan, A. 2015. Cryogenic freezing of fresh date fruits for quality preservation during frozen storage. Journal of the Saudi Society of Agricultural Sciences.

Anyanwu, E.E. 2004. Design and measured performance of a porous evaporative cooler for preservation of fruits and vegetables. Energy Conversion and Management, 45(13-14), 21872195.

Artés, F. 2009. Sustainable sanitation techniques for keeping quality and safety of fresh-cut plant commodities. Postharvest Biology and Technology, 51, 287-296.

Becker, B.R., Fricke, B.A. 2014. Transpiration and Respiration of Fruits and Vegetables. Universidad of Missouri.

Bozkurt, F. 2016. Effect of vaporized ethyl pyruvate as a novel preservation agent for control of postharvest quality and fungal damage of strawberry and cherry fruits. LWT - Food Science and Technology, 65,1044-1049.

Date, A.W. 2012. Heat and mass transfer analysis of a clay-pot refrigerator. International Journal of Heat and Mass Transfer, 55 (15-16), 3977-3983.

Green, D.W., Robert, H.P. Perry's Chemical Engineers' Handbook $8^{\text {th ed }}$. New York. USA : Mc-Graw.

Kasso, M., Bekele, A. 2016. Post-harvest loss and quality deterioration of horticultural crops in Dire 
Dawa Region, Ethiopia. Journal of the Saudi Society of Agricultural Sciences.

$\mathrm{Li}, \mathrm{X}$., Farid, M., 2016. A review on recent development in non-conventional food sterilization technologies. Journal of Food Engineering.

Lovato, M.E., Martín, C.A., Cassano, A.E. 2009. A reaction kinetic model for ozone decomposition in aqueous media valid for neutral and acidic $\mathrm{pH}$. Chemical Engineering Journal, 146(3), 486-497.

Lyu, F. 2016. Effect of pretreatment with carbon monoxide and ozone on the quality of vacuum packaged beef meats. Meat Science, 117,137146.

Miller, F.A., Silva, C.L.M., Brandão, T.R.S. 2013. A Review on Ozone-Based Treatments for Fruit and Vegetables Preservation. Food Engineering Reviews, 5(2), 77-106.

Patil, S. 2014. Influence of high voltage atmospheric cold plasma process parameters and role of relative humidity on inactivation of Bacillus atrophaeus spores inside a sealed package. Journal of Hospital Infection, 88(3), 162-169.
Rakness, K., Gordon, G., Langlais, B. 1996. Guideline for measurement of ozone concentration in the process gas from an ozone generator.

Ramos, B. 2013. Fresh fruits and vegetables - An overview on applied methodologies to improve its quality and safety. Innovative Food Science and Emerging Technologies, 20,1-15.

Sung, T.-L. 2013. Effect of pulse power characteristics and gas flow rate on ozone production in a cylindrical dielectric barrier discharge ozonizer. Vacuum, 90, 65-69.

Watanabe, T. 2015. The influence of inhibit avoid water defect responses by heat pretreatment on hot air drying rate of spinach. Journal of Food Engineering, 168,113-118.

Widdel, F. 2007. Theory and measurement of bacterial growth. Di dalam Grundpraktikum Mikrobiologie, $1-11$. 